\title{
PEMANFAATAN E-BOOK KONSEP ASAM BASA DALAM PEMBELAJARAN KIMIA UNTUK MENINGKATKAN LITERASI KIMIA SISWA SMA KELAS XI
}

\author{
Rd. Nia Elisa Yulianti ${ }^{1 *}$, Anna Permanasari ${ }^{2}$, Leny Heliawati ${ }^{2}$ \\ ${ }^{1)}$ Program Studi Pendidikan IPA, Universitas Pakuan \\ 2) Program Pascasarjana, Universitas Pakuan
}

*Email: niaelisa_yulianti@yahoo.com

\begin{abstract}
Abstrak: Penelitian ini bertujuan untuk memperoleh informasi tentang pemanfaatan $e$-book dalam meningkatkan literasi kimia siswa pada materi asam basa. Dalam penelitian ini digunakan metode pre-eksperimen dengan pre-post test design, disertai dengan analisis deskriptif tentang literasi sains siswa dikaitkan dengan penggunaan e-book sebagai bahan ajar. Subyek penelitian terdiri dari 38 siswa kelas XI dari satu SMA di daerah Bogor, Jawa Barat, dan 3 guru kimia. Instrumen yang digunakan dalam penelitian ini terdiri dari tes literasi dan angket respon siswa serta guru. Hasil penelitian menunjukkan bahwa penggunaan $e$-book asam basa dapat meningkatkan minat siswa yang dibuktikan dari hasil tanggapan siswa. Hampir semua siswa menyatakan sangat menyenangi e-book, dan merasakan manfaatnya dalam belajar asam-basa, Guru juga memberikan respon yang sangat baik, 87\% guru menyatakan bahwa e-book asam-basa sangat memudahkan guru dalam pembelajaran sebagai sumber belajar alternatif. Hasil penelitian lebih lanjut menunjukkan bahwa pemanfaatan e-book dapat meingkatkan literasi sains siswa, dengan peningkatan (Ngain) sebesar 40,2\% (kategori sedang).
\end{abstract}

Kata Kunci: E-book, asam basa, literasi kimia

\section{PENDAHULUAN}

Sistem pembelajaran abad 21 merupakan suatu peralihan pembelajaran dari pembelajaran yang berpusat pada pendidik menjadi pendekatan pembelajaran yang berpusat pada peserta didik. Alismail dan McGuire (2015) mengemukakan pengembang kurikulum mengetahui pentingnya mengembangkan tujuan dan metode pengajaran yang berbeda untuk mempersiapkan siswa di masa depan. Hasilnya adalah pengembangan pengetahuan berbasis 4C yaitu Critical Thinking (berfikir kritis), Communication (komunikasi), Cooperative (kerjasama), dan Creative (kreatif). Dockstader (1999) berpendapat bahwa tugas seorang pendidik bukan hanya menjadi seorang profesional yang mempersiapkan siswa nya untuk abad-21, melainkan juga mempunyai tugas mengintegrasikan teknologi ke dalam kurikulum, dalam hal ini pada konten pembelajaran. 
Turiman dkk (2011) mengatakan bahwa siswa perlu dilengkapi dengan keterampilan abad ke-21 yang terdiri dari empat domain yaitu literasi sains, berfikir kreatif, komunikasi dan produktivitas tinggi. Holbrook and Rannikmae (2009) mengungkapkan bahwa literasi sains terdiri dari (a) Pengetahuan tentang isi substantif sains dan kemampuan untuk membedakannya non-sains; (b) Memahami sains dan aplikasinya; (c) Pengetahuan tentang apa yang dianggap sebagai sains; (d) Kemandirian dalam pembelajaran sains; (e) Kemampuan berpikir ilmiah; (f) Kemampuan untuk menggunakan pengetahuan ilmiah dalam pemecahan masalah; (g) Pengetahuan cerdas dalam isu-isu berbasis sains; (h) Memahami sifat sains; termasuk hubungannya dengan budaya; (i) Apresiasi dan kenyamanan dengan sains, termasuk rasa keingintahuannya; (j) Pengetahuan tentang risiko dan manfaat dari sains dan (k) Kemampuan untuk berpikir kritis tentang sains.

Menurut Durant (dalam Laugksch 1999), literasi sains adalah "apa pun yang harus diketahui publik umum tentang sains". Konsep ini biasanya mengimplikasikan apresiasi terhadap sifat sains, ide dan konsep ilmiah penting dalam sains, dan relevansinya dengan kehidupan sehari-hari. Di Inggris, keaksaraan ilmiah sering disebut sebagai "pemahaman publik tentang sains". OECD (Organization for Economic Cooperation and Development) salah satu lembaga yang mengadakan program penilaian secara internasional menguji secara berkala literasi sains siswa di dunia. Melalui program PISA (Programme for International Student Assesment) tahun 2015 hasil kemampuan literasi sains, membaca, dan matematika siswa-siswi Indonesia pada usia 15 tahun rata-rata berturut-turut berada di peringkat 62, 61, dan 63 dari 69 negara yang dievaluasi.

Dalam Penilaian PISA untuk mata pelajaran IPA diantaranya : Fisika, Kimia, Biologi dan Matematika . Kimia adalah materi IPA yang sulit bagi banyak siswa karena pemahaman konsep dasar tidak cukup dipahami oleh para siswa jika pembelajaran dilakukan secara mandiri. Menurut Johnstone tahun 1991 (Drapper, 2008) untuk memahami kimia memerlukan banyak pemahaman, karena kimia terdiri dari tiga tingkatan: makroskopik yaitu merupakan level representasi kimia yang diperoleh melalui observasi dari fenomena yang dapat dilihat (terlihat) dan dirasakan oleh indera atau bisa menjadi pengalaman sehari-hari peserta didik. Sifat dari representasi makroskopik adalah nyata. Sebagai contoh: warna dan perubahan suhu, $p \mathrm{H}$, pembentukan gas dan presipitat dalam reaksi kimia yang dapat mengamati ketika reaksi kimia berlangsung; level submikroskopik yaitu level representasi yang memberikan penjelasan pada tingkat partikulat. Submikroskopik erat kaitannya dengan model teoritis yang mendasari penjelasan dinamika tingkat partikel (atom, molekul, dan ion).

Mode representasi pada tingkat ini dapat mengekspresikan mulai dari yang sederhana misalnya menggunakan teknologi komputer, menggunakan kata-kata, gambar dua dimensi, gambar tiga dimensi baik diam maupun bergerak (animasi) atau simulasi. Pelajar bisa mewakili pengamatan atau kegiatan laboratorium diberbagai mode representasi, misalnya sebagai laporan tertulis, diskusi, 
presentasi verbal, diagram vee, grafik dan sebagainya; terakhir level Level simbolik (atau ikon) representasi adalah representasi untuk mengidentifikasi entitas (misalnya zat-zat yang terlibat dalam reaksi kimia) dengan menggunakan bahasa simbolis kualitatif dan kuantitatif, seperti rumus kimia, diagram, gambar, persamaan, stoikiometri, dan perhitungan matematis.

Cardellini (2012) mengungkapkan ada beberapa hal yang membuat siswa merasa kesulitan untuk memahami konsep-konsep kimia asam basa , antara lain : 1) Sifat ilmu kimia itu sendiri yang terdiri dari tiga level membuatnya sulit untuk dipelajari sendiri 2) Metode-metode yang telah kita ajarkan secara tradisional (ceramah) 3) Metode pembelajaran selama ini yang membuat konflik belajar memahami kimia semakin dalam.

Untuk itu diperlukan suatu proses pembelajaran yang menggunakan sumber ajar yang bisa langsung diakses siswa secara mandiri. Maka perlu adanya pengembangan sumber ajar dalam hal ini bahan ajar. Darliana (2005) mengungkapkan bahwa kelemahan pendidikan sains di Indonesia terutama terletak pada lemahnya cara mengajarkan keterampilan proses dan orientasi pembelajaran sains kepada siswa dan penerapannya dalam kehidupan sehari-hari. Selain itu, ketersediaan bahan ajar juga harus menjadi perhatian para pendidik. Bahan ajar yang baik seharusnya menunjukkan keseimbangan antara melatih konsep, proses, dan sikap.

Adisendjaja (2008) melaporkan hasil penelitiannya terhadap tiga buku ajar sains yang dianalisis menyatakan bahwa proporsi antara konten sains, kemampuan proses sains dan kemampuan konteks sains dalam bahan ajar yang ditelitinya masih relatif rendah. Usaha yang dapat dilakukan untuk meningkatkan kualitas pendidikan sains di Indonesia yaitu antara lain dengan cara memperkaya bahan ajar sains yang berorientasi pada peningkatan literasi sains siswa.

Depdiknas (2010) bahan ajar dikelompokkan menjadi 6 jenis, yaitu: 1) bahan ajar cetak 2) bahan ajar dengar 3) bahan ajar pandang dengar 4) bahan ajar multimedia interaktif 5) bahan ajar berbasis web dan 6) bahan ajar elektronik book (e-book).

Bahan ajar e-book adalah singkatan dari elektronik book atau buku elektronik. Vassiliou dan Rowley (2008) berpendapat e-book adalah sebuah bentuk buku dalam versi digital, yang dapat dibaca pada komputer pribadi atau perangkat genggam yang dirancang khusus untuk tujuan tersebut. e-book yang digunakan dikemas dalam bentuk pdf, exe, word, html, txt dan lain-lain, aplikasi pembuatan e-book yang sering digunakan adalah Sigil, Callibre,MOBI, aPUBeeMaker dan Flip Book Pdf. Tujuan dan fungsi $e$-book adalah salah satu alternatif sumber belajar yang dapat memuat konten multimedia di dalamnya. E-book dapat menyajikan bahan ajar yang lebih menarik dan membuat pembelajaran lebih menyenangkan (Sadiah, 2008). Seiring dengan perkembangan global termasuk IT, maka pengembangan $e$-book sangat relevansi dilakukan.

Dalam konteks bahan ajar dalam pembelajaran kimia, masih sedikit sumber belajar tersedia dalam bentuk $e$-book. Materi yang potensial dikembangkan dalam 
bentuk $e$-book adalah materi asam basa. Selama ini buku ajar kimia pada materi asam basa lebih mengarah kepada penanaman konsep dan perhitungan kimia kepada siswa, sementara aspek keterampilan dan sikap masih terabaikan. Melalui penelitian terdahulu telah dikembangkan e-book Kimia Asam Basa yang diharapkan dapat mengakomodasi kebutuhan pencapaian tujuan pembelajaran yaitu penguasaan konsep, keterampilan dan sikap berdasarkan konteks kehidupan sehari-hari berbasis literasi kimia, selain itu diharapkan dapat membantu guru dalam memfasilitasi proses pembelajaran bukan saja secara teori namun juga secara praktikal dengan menyajikan video percobaan yang disertai LKS nya guna memudahkan siswa lebih memahami konsep asam basa. Penelitian berikutnya adalah pemanfataan e-book yang telah dikembangkan dalam pembelajaran kimia. Telah diteliti profil literasi kimia siswa setelah pembelajaran menggunakan bahan ajar e-book.

\section{METODE}

Penelitian selanjutnya dilakukan untuk memperoleh informasi tentang efektifitas e-book dalam meningkatkan literasi Sains Siswa. Metode penelitian yang digunakan adalah pre-eksperimen dengan Pre Test - Post Test Only Design. Dari kegiatan penelitian yang telah dilakukan, diperoleh data skor pretes, postes, dan N-Gain tentang literasi kimia siswa kelas eksperimen serta profilnya.

Pembelajaran dilakukan dengan menggunakan model pembelajaran discovery learning. Pretest dilakukan sebelum pembelajaran di mulai dengan melakukan test 20 soal literasi kimia. Tanggapan siswa dan guru sangat penting diketahui untuk melihat efektifitas penggunaan $e$-book.

\section{HASIL DAN PEMBAHASAN}

Pelaksanaan pembelajaran dilakukan sesuai dengan rencana pembelajaran yang telah disusun. Pembelajaran dilakukan pada siswa kelas XI sebanyak 38 siswa. Pembelajaran diawali dengan diskusi kelompok tentang asam basa dengan mengamati secara seksama konsep asam basa yang disajikan dalam bentuk gambar, video pembelajaran yang dipresentasikan dengan powerpoint dengan model pembelajaran discovery learning. Setelah selesai pembelajaran siswa diminta menyusun daftar pertanyaan dari konsep asam basa yang tidak difahami. Dalam forum diskusi kelas peserta didik dengan bimbingan guru membahas bersama-sama tentang konsep asam basa berdasarkan pertanyaan yang diberikan dan menuliskan resumenya.

Setelah pembelajaran selesai dilakukan, guru memberikan tes tertulis berbasis literasi tentang konsep asam basa sebanyak 20 butir soal. Hasil dari ratarata nilai pretes yang dihasilkan adalah 53,16. Pembelajaran kemudian dilakukan dengan menggunakan e-book Asam Basa yang sudah di validasi sebagai sumber belajar dengan model pembelajaran yang sama yaitu discovery learning. Selesai 
pembelajaran, peserta didik diberikan postest dengan soal literasi sebanyak 20 butir soal. Efektifitas bahan ajar pada pembelajaran dilihat dampaknya terhadap peningkatan literasi kimia siswa. Hasil penelitian yang sudah dilakukan melalui pretes dan potstes diperoleh data mentah yang dihitung dan dianalisis untuk dijadikan dasar dalam menarik kesimpulan dari perhitungan N-Gain. Dari 20 butir pretest dan posttest yang diujikan di dalam penelitian pada 38 responden diperoleh hasil dengan menggunakan aplikasi analisis butir soal dari PSMA.

Untuk melihat peningkatan literasi kimia lebih jauh dilakukan analisis dengan perhitungan N-Gain. Nilai N-Gain dikonversi dalam bentuk persentase. Pada bagian ini akan dijabarkan efektifitas bahan ajar $e$-book materi asam basa terhadap hasil literasi kimia siswa. Secara keseluruhan maupun terhadap setiap domain literasi sains yaitu domain kompetensi sains, pengetahuan sains dan sikap sains.

Berdasarkan hasil analisa pretes dan postes, dapat dilihat ada nya kenaikan nilai literasi kimia berdasarkan setiap domain, dengan rincian sebagai berikut: domain kompetensi mendapatkan jumlah skor 4, domain pengetahuan mendapatkan jumlah skor 96, domain sikap mendapatkan jumlah skor 5. Rata-rata nilai yang dihasilkan: pretes 53,16; postes 68,29. Secara umum nilai yang dihasilkan siswa belum mencapai KKM namun sudah menunjukkan adanya kenaikan literasi kimia. Capaian literasi kimia secara keseluruhan baik pretes maupun postes dilihat dari domain pengetahuan, kompetensi dan sikap sains disajikan pada Gambar 1.

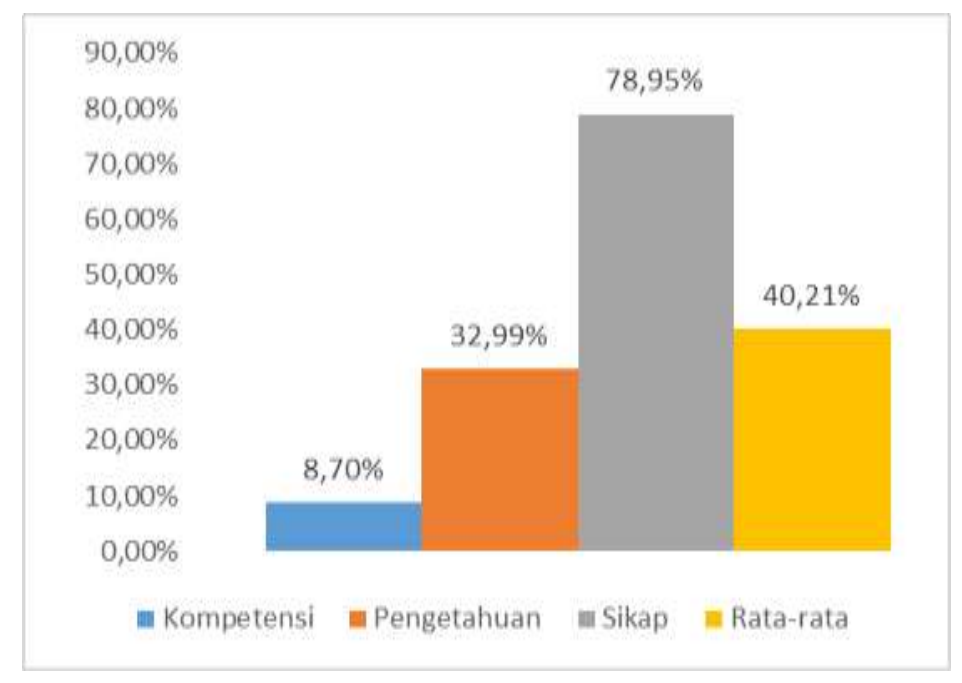

Gambar 1. Hasil N-Gain literasi kimia setiap domain dan rata-rata

Pada gambar di atas dapat dilihat nilai hasil literasi kimia asam basa dengan nilai domain kompetensi sebesar 8,7\%; domain pengetahuan $32,99 \%$ dan domain 
sikap 78,95\%. Untuk melihat efektifitas bahan ajar e-book kimia asam basa dapat meningkatkan literasi kimia yaitu dengan mencari nilai N-Gain. Kriteria digunakan dalam menentukan nilai $\mathrm{N}$-Gain adalah persamaan yang dianut oleh Hake (1999) Dari grafik dapat dilihat nilai N-Gain sebesar 40,21\%, dengan katagori sedang. Hasil tersebut di dukung oleh penelitian Firdaus (2016) yang mengatakan bahwa penggunaan interactive e-book IPA dapat meningkatkan literasi sains siswa.

Faktor meningkatnya literasi siswa adalah adanya video pembelajaran yang ditautkan ke dalam e-book, sehingga siswa dapat lebih memahami konsep-konsep yang bersifat abstrak dan membutuhkan penjelasan secara mendalam, dan ini umumnya yang lebih disukai siswa. Selain itu, dalam e-book Asam basa juga disisipkan tautan quiz soal interaktif, dimana siswa bisa menguji pemahaman materi dengan diketahui nilai akhir pada quiz tersebut. Setelah pembelajaran, siswa diminta untuk memberikan respon terhadap pembelajaran yang telah dilakukan dengan menggunakan angket yang telah disediakan. Tanggapan Siswa terhadap e-book Asam Basa sangat baik untuk dijadikan sumber belajar dikarenakan dapat menambah pemahaman siswa terutama dalam e-book ini disisipkan tautan gambar dan video pembelajaran yang membantu siswa dalam pemahaman konsep tertentu.

Adapun hasil tanggapan siswa terhadap e-book Asam Basa pada aspek tampilan memiliki nilai $83 \%$, pada aspek penyajian memiliki nilai $84 \%$, pada aspek manfaat $83 \%$. Sehingga rata-rata dari tanggapan siswa adalah $83,00 \%$ dengan kategori sangat baik. Siswa beranggapan bahwa e-book tersebut dapat membantu memahami konsep asam basa dan memberikan kesan yang berbeda dari pembelajaran biasanya. Penggunaan video percobaan juga membantu siswa untuk mempelajari aplikasi konsep asam basa dengan mengamati percobaan dimana saja tanpa harus melaksanakannya di laboratorium.

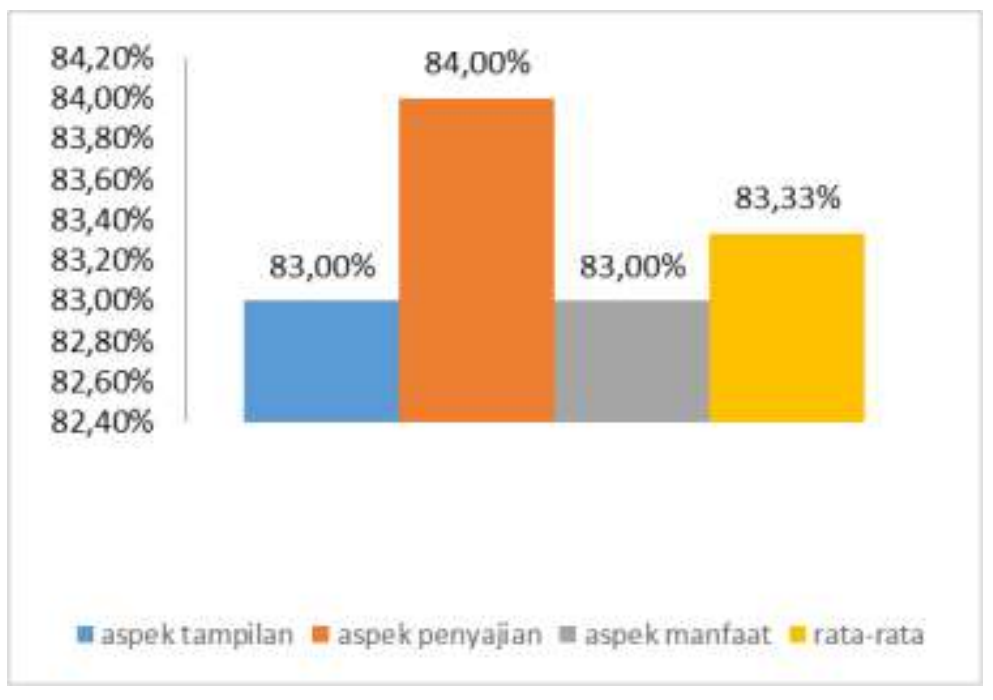


Gambar 2. Hasil tanggapan siswa terhadap e-book Asam Basa

Siswa tertarik dengan e-book Kimia Asam Basa ini karena dapat digunakan di Handphone berbasis Android dengan terlebih dahulu menginstall aplikasi nya. Tampilan e-book Kimia Asam Basa di sajikan pada Gambar 3a. Sementara itu, $e$ book dapat pula digunakan pada laptop atau notebook, dengan cara sedikit berbeda dengan yang digunakan pada Handphone Android, meskipun pada prinsipnya konten yang dikandungnya sama. Tampilan $e$-book pada media laptop atau notebook disajikan pada Gambar 3b.
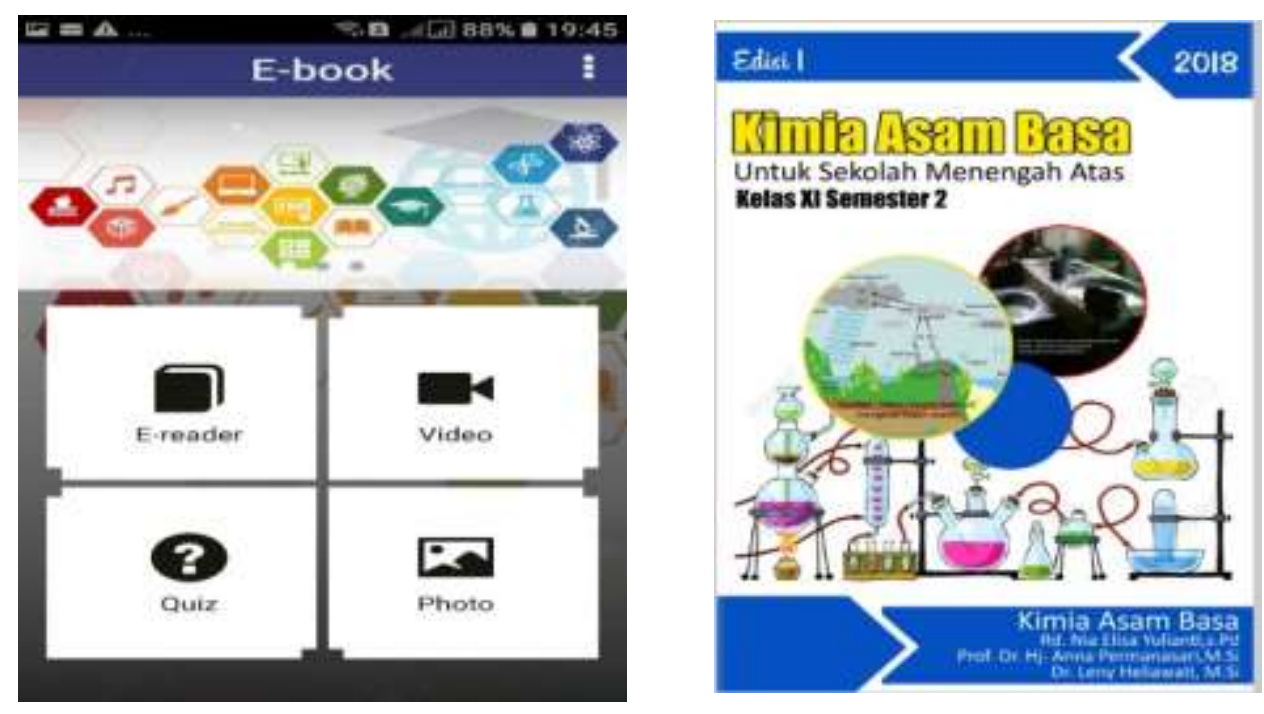

Gambar 3. (a) Tampilan e-book Asam Basa pada HP Android Tampilan e-book, (b) Asam Basa pada penggunaan laptop/note book

Secara keseluruhan, e-book membuat siswa senang belajar asam-basa, karena e-book asam basa yang telah dikembangkan memiliki karakteristik: tampilan dari $e$-book asam basa sama seperti halnya bahan ajar buku hanya dalam bentuk digital, konten e-book asam basa ini terdiri dari teks, gambar, video dan animasi pembelajaran serta soal interaktif.

Respon siswa terhadap pemanfaatan e-book sejalan dengan tanggapan para guru.Tanggapan Guru terhadap e-book Asam Basa dinilai sangat baik untuk dijadikan sumber belajar dikarenakan dapat menambah pemahaman siswa terutama dalam $e$-book ini disisipkan tautan gambar dan video pembelajaran yang 
membantu siswa dalam pemahaman konsep tertentu. Sehingga penggunaan bahan ajar ini diharapkan dapat membantu menaikkan siswa dalam mencapai KKM nya.

Instrumen tanggapan guru terhadap e-book Asam Basa yang diberikan kepada guru terdiri atas aspek ketertarikan, aspek susunan materi, aspek petercapaian pemahaman materi, aspek kemudahan penggunaan bahan ajar , aspek pengaruh bahan ajar terhadap kreativisme siswa dan aspek kandungan materi e-book terhadap konteks asam basa dalam kehidupan sehari-hari. Data lengkap dapat dilihat pada lampiran. Hasil tanggapan guru terhadap e-book yaitu sebesar $87 \%$ dengan kategori sangat baik. Dengan adanya penambahan tautan video, animasi, dan quiz creator memudahkan guru untuk menjelaskan konsep kimia yang bersifat abstrak. Sejalan dengan hasil penelitian Hasbiyati (2017) bahwa $e$-book dapat mempermudah guru dalam kegiatan pembelajaran.

\section{PENUTUP}

Berdasarkan temuan dalam penelitian dapat disimpulkan bahwa penggunaan e-book asam basa dalam pembelajaran dapat meningkatkan hasil literasi kimia siswa. Penggunaan e-book Kimia Asam Basa secara umum ditanggapi dengan sangat baik oleh siswa. Menurut siswa $e$-book Kimia Asam Basa dapat membantu siswa dalam meningkat literasi kimia dan motivasi belajar. Hasil tanggapan guru terhadap e-book yaitu sangat baik. Dengan adanya penambahan tautan video, animasi, dan quiz creator memudahkan guru untuk menjelaskan konsep kimia yang bersifat abstrak.

\section{REFERENSI}

Adisendjaja, Y, H. (2007). Analisis Buku Ajar Biologi SMA Kelas X SMA Kelas $\mathrm{X}$ di Kota Bandung Berdasarkan Literasi Sains. Jurnal Pendidikan Biologi

Alismail, H, A. McGuire, P. (2015). 21st Century Standards and Curriculum: Current Research and Practice. Journal of Education and Practice.

Cardellini. (2012). Chemistry: Why the Subject is difficult?. Universidad Nacional Autonama de Mexico. Educ Quim, 242

Depdiknas. (2006). Panduan Pengembangan Pembelajaran IPA Terpadu. Jakarta: Puskur Balitbang Depdiknas

Depdiknas. (2007). Peraturan Pemerintah Nomor 20 Tahun 2007 tentang Standar Penilaian Pendidikan. Jakarta: Depdiknas

Draper, S. (2008). The three types of kowledge in chemistry. Deparment of Psychology. University of Glasgow

Dockstader, J. (1999). Teachers of the 21 st century know the what, why, and how of technology integration. Diakses dari https://thejournal.com/Articles/1999/01/01/Teachers-of-the-21st-CenturyKnow-the-What-Why-and-How-of-Technology-Integration.aspx 
Hake, R. R. 1999. Analyzing Changel Gain Score. American Educational Research Methodology.

Holbrook, J. Rannikmae. M. (2009). The Meaning of Scientific Literacy. International Journal of Environmental \& Science Education, 4.

Laugksch, R.,C. (1999). Scientific Literacy: A Conceptual Overview. University of Cape Town: School of Education

Turiman, P. Omar, J. Daud, A. \& Osman, K. (2012). Fostering the 21st Century Skills through Scientific Literacy and Science Process Skills. Procedia Social and Behavioral Sciences, 59

Vassiliou, R. J. (2008). Progressing the definition of "e-book". Journal of Libraries and Information Science. 